JURNAL MAKSIPRENEUR, Vol. VII, No. 1, Desember 2017, hal. 73-93

\title{
HIGH-PERFORMANCE ORGANIZATION UNTUK MENGHADAPI TURBULENSI LINGKUNGAN BISNIS
}

\author{
Andriya Risdwiyanto \\ Fakultas Ekonomi dan Bisnis, Universitas Airlangga, Surabaya \\ Korespondensi penulis: andriya.risdwiyanto-2014@feb.unair.ac.id
}

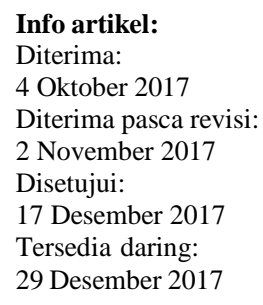

\begin{abstract}
Today's businesses face unprecedented challenges. Leaders are confronted with increased competition, globalization, demand for growing social responsibilities, technological changes, and new strategic thinking. These need to be managed to build and sustain a high-performance organization (AMA, 2007). The organizational environment is anything that is around an organization that has an influence, either directly or
\end{abstract}

indirectly on the process of organization operations. Every organization, either a profit organization and a non-profit organization, such as mass organizations, foundations, and others, want growth and sustainability in every activity. Organizational development does play an important role in helping organizations to transform themselves, through highly planned strategies and with predictions of problems that may be addressed through solutions. The organization will need more ability to react quickly and anticipate the various turbulences it faces appropriately. High-performance organization (HPO) is a solution to face increasingly unpredictable changes.

Keywords: High-performance organization, turbulence, organizational development.

\section{PENDAHULUAN}

Sumber daya manusia (SDM) merupakan elemen utama organisasi dibandingkan dengan elemen lain seperti modal, teknologi, dan uang karena manusia itu sendiri yang mengendalikan sumber daya yang lain. Sumber daya manusia tidak terlepas dari kegiatan-kegiatan atau proses manajemen lainnya seperti strategi perencanaan, pengembangan manajemen, dan pengembangan organisasi. Hubungan antara aspek-aspek manajemen itu sangat erat, sehingga sulit untuk menghindari pembicaraan secara terpisah satu dengan lainnya.

Pengembangan SDM dan organisasi menjadi sebuah keniscayaan bagi setiap organisasi, karena penempatan karyawan secara langsung dalam pekerjaan tidak menjamin mereka akan berhasil. Karyawan baru sering merasa tidak pasti tentang peranan dan tanggung jawab mereka. Permintaan pekerjaan dan kapasitas karyawan haruslah seimbang melalui program orientasi dan pelatihan. Karyawan yang telah dilatih dan menguasai pekerjaannya, mereka membutuhkan pengembangan lebih lanjut untuk menyiapkan tanggung jawab dan jalur karir mereka di 
masa depan. Kecenderungan yang terus terjadi adalah semakin beragamnya karyawan dengan berbagai latar belakang, organisasi yang lebih datar, dan persaingan global yang meningkat. Upaya pelatihan dan pengembangan dapat mendorong karyawan mampu mengembangkan tugas, kewajiban, dan tanggung jawab yang lebih besar.

Lingkungan di mana organisasi berada tidaklah bersifat statis, tetapi dinamis, berubah-ubah, mengikuti trend perkembangan dan perubahan zaman. Perubahan yang terjadi pada lingkungan organisasi penuh ketidakpastian. Apabila organisasi ingin tetap bertahan dan berkembang, maka organisasi harus fleksibel dan mampu beradaptasi dengan perubahan lingkungan tersebut. Untuk beradaptasi dengan perubahan lingkungan, setiap organisasi dituntut untuk belajar atau disebut dengan organisasi pembelajar (learning organization) agar lebih responsif terhadap lingkungan maupun tuntutan dari dalam organisasi. Dengan mengetahui keadaan lingkungan, organisasi dapat mengantisipasi dan mengambil keputusankeputusan yang tepat demi kemajuan organisasi (Senge, 2010).

Banyak hasil penelitian tentang learning organization menunjukkan bahwa untuk menjadi organisasi yang tangguh di masa depan yang penuh tantangan, maka perlu peningkatan faktor keahlian pribadi sumber daya manusia, pemahaman bersama terhadap visi organisasi dan pembelajaran tim (Kusmayadi, 2008). Setiap organisasi, baik organisasi yang bersifat profit, seperti perusahaan maupun organisasi yang bersifat non-profit, seperti organisasi massa, yayasan, dan lain-lain, menginginkan adanya pertumbuhan dan keberlanjutan dalam setiap aktivitasnya. Namun, sayangnya tidak semua organisasi mampu menciptakan pertumbuhan dan mempertahankan keberlanjutan aktivitasnya. Tulisan ini mencoba merefleksikan sebuah pemikiran mengenai fakta turbulensi lingkungan bisnis yang semakin tinggi, sehingga memerlukan organisasi yang adaptif dan memiliki kemampuan untuk meningkatkan kinerja organisasi agar lebih optimal.

\section{ORGANISASI}

Mengorganisasi adalah suatu tindakan secara sadar untuk mengkoordinasikan unit sosial, yang terbangun dari dua orang atau lebih yang berfungsi atas dasar keberlanjutan secara relatif untuk mencapai tujuan atau sekumpulan tujuan bersama. Dengan pengertian ini, perusahaan manufaktur dan jasa merupakan organisasi, demikian pula halnya dengan sekolah, rumah sakit, gereja, unit militer, toko eceran, kesatuan polisi, dan lembaga-lembaga pemerintah baik daerah maupun pusat (Robbins, 2013). Orang-orang yang memantau aktivitas orang lain dan bertanggungjawab untuk pencapaian tujuan organisasi disebut manajer (untuk organisasi yang bergerak di bidang non profit dinamakan administrator). Keperilakuan secara umum dapat diprediksikan dan dalam suatu studi keperilakuan yang sistematis merupakan alat untuk membuat prediksi yang lebih akurat. Penggunaan pengertian studi sistematis diartikan sebagai upaya pencarian hubungan yang mempengaruhi atribut sebab dan akibat, serta mendasarkan kesimpulan bukti ilmiah, yaitu data yang dikumpulkan atas dasar kondisi tertentu dan terukur, serta dapat diinterpretasikan dalam suatu pengertian yang logis.

Secara umum, organisasi dibedakan dua macam dilihat dari orientasi operasinya, yaitu organisasi yang berorientasi profit dan non profit. Keberhasilan atau pun kegagalan organisasi tidak dapat dilepaskan dari masalah lingkungan yan (Luthans, 2011). g dihadapinya. Lingkungan bisnis melalui elemen-elemennya, di 
samping dapat mendorong sekaligus dapat menghambat aktivitas dan perkembangan bisnis. Sebagai suatu sistem yang terbuka, organisasi berinteraksi dengan faktor-faktor lingkungan di sekelilingnya. Lingkungan mempunyai hubungan timbal balik, dalam arti bisnis yang dipengaruhi lingkungan, dan sebaliknya lingkungan juga dipengaruhi bisnis. Pengaruh lingkungan dapat secara langsung maupun tidak langsung terhadap kegiatan bisnis.

\section{PERILAKU ORGANISASIONAL}

Menurut Robbins (2013), perilaku organisasional adalah suatu bidang studi yang menyelidiki dampak perorangan, kelompok, dan struktur pada perilaku di dalam organisasi dengan maksud menerapkan pengetahuan untuk memperbaiki keefektifan organisasi. Perilaku organisasional mempelajari tiga pendekatan perilaku, yakni perorangan, kelompok dan struktur. Dari pernyataan tersebut, perilaku organisasional dapat didefinisikan sebagai studi mengenai apa yang dilakukan orang-orang dan kelompok-kelompok dalam suatu organisasi dan bagaimana perilaku mereka mempengaruhi kinerja organisasi tersebut. Perilaku organisasi merupakan ilmu keperilakuan terapan untuk mengkaji manfaat dari individual, kelompok, dan dampak struktur perilaku dalam rangka membuat organisasi dapat beroperasi lebih efektif berdasarkan kontribusi dari sejumlah bidang disiplin keperilakuan. Bidang-bidang tersebut meliputi psikologi, sosiologi, psikologi sosial, dan antropologi. Kontribusi psikologi terutama pada tingkat individu atau mikro, sedangkan ketiga disiplin yang lain memberikan kontribusi pemahaman terhadap aspek makronya.

\section{DIMENSI POKOK TEORI ORGANISASI}

Dimensi-dimensi pokok teori organisasi terdiri atas dimensi teknis, konsep, dan manusia. Dimensi teknis teori organisasi adalah dimensi yang menekankan pada kecakapan atau kemampuan seseorang yang dibutuhkan untuk menggerakkan organisasi. Yang diperlukan adalah sumber daya yang memiliki ketrampilanketrampilan dalam mengelola sebuah organisasi. Dimensi ini berisi keahliankeahlian birokrat atau manajer di bidang teknis atau orang yang ahli dan mempunyai kemampuan yang diperlukan untuk menggerakkan organisasi, misalnya keahlian dalam mengoperasikan komputer, memahami konsep pemasaran, serta mampu dalam penyalurannya, dan lain-lain.

Dimensi konsep adalah sebuah rancangan khusus yang dijadikan sebagai acuan dalam menjalankan sebuah organisasi, artinya setiap gerak atau kegiatan yang akan dilaksanakan tetap mengacu pada pedoman yang telah dibuat oleh seluruh atau sebagian anggota organisasi yang mempunyai wewenang. Selain itu, dimensi konsep merupakan motor penggerak dimensi pertama dan amat erat hubungannya dengan dimensi ketiga yakni dimensi manusia. Dimensi manusia adalah dimensi yang paling utama dalam sebuah organisasi, karena tanpa adanya dimensi manusia, suatu organisasi tidak akan pernah ada karena tidak ada yang membuat organisasi dalam arti membentuk sebuah organisasi dan tidak ada penggerak yang melakukan kegiatan oragnisasi tersebut. Dimensi manusia merupakan dimensi yang kompleks dalam sebuah organisasi. Namun, dimensi manusia tidak akan berfungsi secara utuh jika dimensi teknis dan konsep tidak ada. 


\section{RERANGKA DASAR PERILAKU ORGANISASI}

Rerangka dasar perilaku organisasi terletak pada dua komponen, yaitu individu-individu yang berperilaku, baik itu perilaku secara individu, perilaku kelompok, dan perilaku organisasi. Komponen kedua adalah organisasi formal sebagai wadah perilaku tersebut sebagai sarana bagi individu yang ditandai dengan keterlibatan dan perannya di dalam kegiatan organisasi. Pengertian perilaku organisasi menurut Robbins (2013) adalah suatu bidang studi yang menyelidiki dampak perorangan, kelompok, dan struktur pada perilaku di dalam organisasi dengan maksud untuk menerapkan pengetahuan semacam itu dalam upaya memperbaiki keefektifan organisasi.

\section{LINGKUNGAN ORGANISASI}

Lingkungan organisasi adalah segala sesuatu yang berada di sekitar organisasi yang memiliki pengaruh, baik secara langsung maupun tidak langsung pada proses operasi oarganisasi. Menurut Peranginangin (2013) serta Kusmayadi (2008), lingkungan merupakan faktor yang sangat berperan terhadap kondisi organisasi, karena faktor ini sangat menentukan strategi yang akan dijalankan organisasi. Strategi organisasi akan ditentukan oleh kekuatan-kekuatan lingkungan. Secara umum, lingkungan organisasi dibe-dakan dalam dua kelompok, yaitu lingkungan internal dan eksternal organisasi (Gambar 1). Nickels, et.al. (2009) menyatakan bahwa lingkungan bisnis terdiri atas faktor-faktor sekitar oraganisasi yang dapat membantu atau pun menghambat perkembangan bisnisnya.

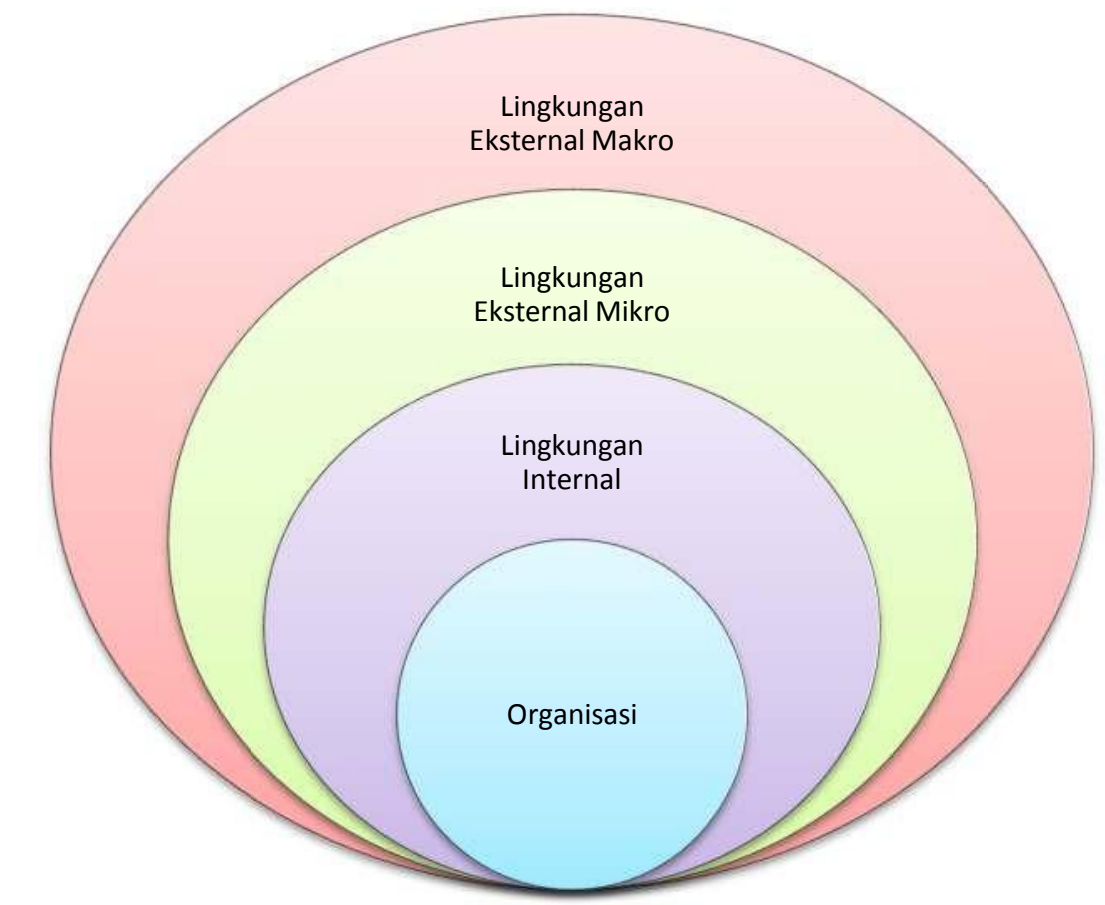

Sumber: Robbins (2013) diadaptasi dan diilustrasikan.

\section{Gambar 1. Lingkungan Organisasi}

Lingkungan internal adalah faktor-faktor yang mempengaruhi organisasi dan berada di dalamnya, sedangkan lingkungan eksternal adalah faktor-faktor di luar organisasi yang mempengaruhi kegiatannya. Lingkungan eksternal terbagi 
lagi menjadi dua macam, yaitu lingkungan mikro dan lingkungan makro. Lingkungan mikro adalah lingkungan eksternal yang berpengaruh secara langsung terhadap kegiatan organisasi. Lingkungan mikro yang memberikan pengaruh langsung pada organisasi di antaranya adalah:

1. Pemasok (supplier) yaitu pihak yang menunjang kelangsungan operasi organisasi melalui pasokan kebutuhan organisasi.

2. Perantara, misalnya distributor dan pengecer yang berperan dalam pendistribusian hasil-hasil produksi kepada konsumen atau pasar.

3. Konsumen sebagai pasar sasaran dan yang menggunakan produk yang dihasilkan organisasi.

4. Investor atau kreditor adalah pihak yang mendukung kebutuhan pendanaan bagi kelangsungan operasi organisasi melalui suatu kesepakatan tertentu.

Lingkungan makro adalah lingkungan eksternal yang memberikan pengaruh secara tidak langsung terhadap organisasi, yaitu lingkungan demografi, perekonomian, hukum dan politik, sosial dan budaya, teknologi, ekologi, persaingan, dan global atau internasional. Gambar 2 berikut ini menggambarkan pengaruh timbal balik antara organisasi dan faktor-faktor eksternal secara makro. Pengaruh setiap faktor eksternal tidak hanya dirasakan oleh organisasi, tetapi juga oleh pihak lain seperti organisasi yang terlibat dalam penyediaan input, pendistribusian output, dan proses konsumsi oleh konsumen atau pasar.

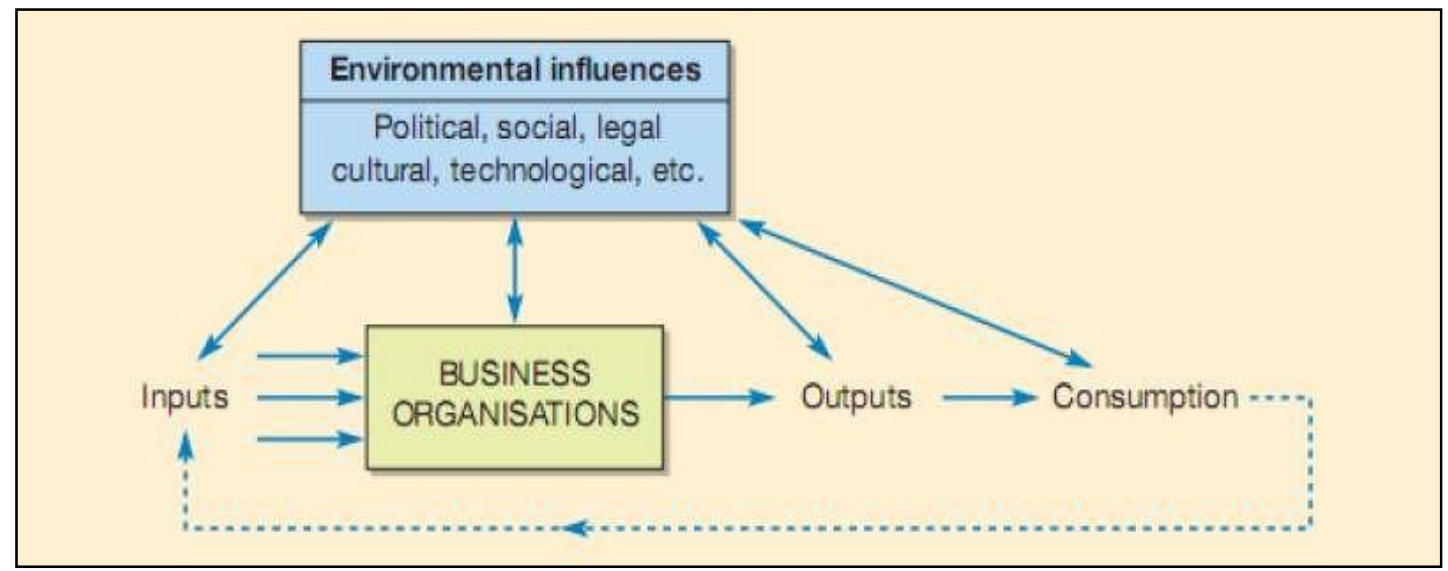

Sumber: Robbins (2013).

\section{Gambar 2. Lingkungan Eksternal Makro bagi Organisasi}

\section{PERUBAHAN DALAM ORGANISASI}

Perubahan organisasi merupakan masalah krusial bagi organisasi pada masa sekarang ini termasuk masa depan. Ketika perubahan telah menjadi suatu kebiasaan atau rutinitas, maka organisasi pun akan mendapatkan pengaruh atas perubahan lingkungannya. Hal ini sebenarnya merupakan proses ketika sebuah organisasi mengoptimalkan kinerja menuju kondisi ideal. Chen et al. (2013) mengungkapkan bahwa perubahan organisasi selalu terjadi sebagai reaksi terhadap lingkungan yang berubah, respon terhadap situasi krisis saat ini, atau dipicu oleh kebijakan seorang pemimpin. Perubahan organisasi yang berhasil bukan hanya dalam proses penyesuaian, tetapi juga memerlukan pengelolaan kemampuan yang memadai. Banyak faktor yang menjadi penyebab terjadinya perubahan organisasi, meliputi unsur-unsur, pendekatan, proses, resistensi, mana- 
jemen, dan termasuk faktor-faktor yang mungkin menyebabkan kerusakan organisasi.

Apa sebenarnya yang dimaksud perubahan organisasi? Mengapa sebuah organisasi perlu perubahan organisasi? Secara perspektif pasif, perubahan organisasi terjadi sebagai suatu reaksi terhadap lingkungan yang selalu berubah. Di sisi lain, sudut pandang yang lebih proaktif menyatakan bahwa hal itu lebih dipicu oleh manajer yang progresif. Selain itu, perubahan organisasi sangat jelas terlihat ketika organisasi baru saja mengalami perubahan kepemimpinan (Haveman, Russo \& Meyer, 2001). Secara global, lingkungan dunia usaha saat ini berada dalam masa transisi dari era revolusi industri menuju era revolusi informasi dan komunikasi. Komunikasi informasi makin bermutu dan cepat menyebabkan perubahan lingkungan yang cepat, dinamis, dan kompleks. Perubahan tersebut tidak hanya bersifat evolusioner, tetapi seringkali bahkan bersifat revolusioner.

Tabel 1. Lima Perubahan pada Era Revolusi Industri dan Revolusi Informasi

\begin{tabular}{ll}
\hline \multicolumn{1}{c}{ Era Revolusi Industri } & \multicolumn{1}{c}{ Era Revolusi Informasi } \\
\hline $\begin{array}{l}\text { Evolusi dari custom products, small batch } \\
\text { products, large batch products, dan akhirnya } \\
\text { commodity products. }\end{array}$ & $\begin{array}{l}\text { Perubahan dari commodity products ke large } \\
\text { batch products, small batch products, dan } \\
\text { akhirnya kembali ke } \text { custom products. }\end{array}$ \\
\hline $\begin{array}{l}\text { Kecenderungan untuk melakukan vertical } \\
\text { integration (administrative hierarchies). }\end{array}$ & $\begin{array}{l}\text { Kecenderungan ke arah mekanisme pasar } \\
\text { (market mechanism). }\end{array}$ \\
\hline Konsumen belum terlalu choosy. & Konsumen cenderung makin choosy. \\
\hline Big is beautiful. & Small is beautiful. \\
\hline Product life cycle relatif panjang. & Product life cycle makin pendek. \\
\hline $\begin{array}{l}\text { Persaingan dalam skala nasional dan } \\
\text { internasional. }\end{array}$ & Persaingan dalam skala global GATT, APEC, \\
\hline Sumber: Kusmayadi (2008). & AEC.
\end{tabular}

Perubahan era mendorong terjadinya perubahan dalam paradigma organisasi dan manajemen. Sistem dan sub-sistem organisasi bergerak dari close systems ke arah open systems. Sebagai dampak dari kemajuan teknologi informasi dan komunikasi (TIK) tidak hanya meningkatkan keterkaitan hubungan antarmanusia, tetapi juga hubungan antarindustri dan antarsistem serta subsistem organisasi lain yang merupakan suatu jaringan (net working organizations). Meluasnya relational contracting, baik antarperusahaan dalam industri yang sama maupun berbeda dan bahkan antarnegara merupakan indikator terjadinya perubahan dalam paradigma organisasi dan manajemen. Pada saat ini, terjadi perkembangan teknologi dalam tiga sektor utama (Prakarsa, 1994), yaitu: (1) teknologi transportasi, (2) teknologi manufaktur, dan (3) teknologi informasi dan komunikasi. Misalnya, perkembangan teknologi transportasi memungkinkan produk berupa barang dan jasa mengalir dari bagian dunia yang satu ke bagian dunia yang lain dengan jumlah relatif besar, dalam waktu relatif singkat, serta dalam harga yang relatif murah.

Schneider dan Somers (2006) menyatakan bahwa banyak masalah organisasi yang telah ada dari masa sebelumnya, terutama bagaimana mencegah manajerialisme, yaitu manipulasi korporasi oleh isu-isu manajemen yang banyak mengalami perubahan. Gagasan tentang organisasi telah berkembang dari birokrasi dengan batas-batas yang jelas dan daerah internal otoritas menjadi bentuk baru yang memiliki batas-batas eksternal dan internal yang fleksibel. 
Namun, kepemimpinan telah lama menjadi area kajian dan pengembangan baru. Orlikowski dan Hofman (1997) menyebutkan bahwa cara-cara berpikir tradisional tentang perubahan berbasis teknologi berakar pada konsep Kurt Lewins yang menyebutkan adanya tiga tahap model perubahan yaitu "unfreezing," "change," dan "refreezing." Menurut model ini, organisasi mempersiapkan diri menghadapi perubahan, mengimplementasikan perubahan, dan kemudian berusaha untuk mendapatkan kembali stabilitas secepat mungkin. Seperti model lainnya, perubahan akan memperlakukan suatu peristiwa yang dikelola selama jangka waktu tertentu, kemungkinan bisa cocok untuk organisasi yang relatif stabil dan dibatasi fungsi yang telah cukup tetap untuk memungkinkan spesifikasi rinci. Bagaimana pun, mengingat lingkungan saat ini lebih bergolak, turbulen, dan penuh ketidakpastian, maka model pendekatan organisasi dan kondisi lingkungan seperti itu menjadi kurang tepat.

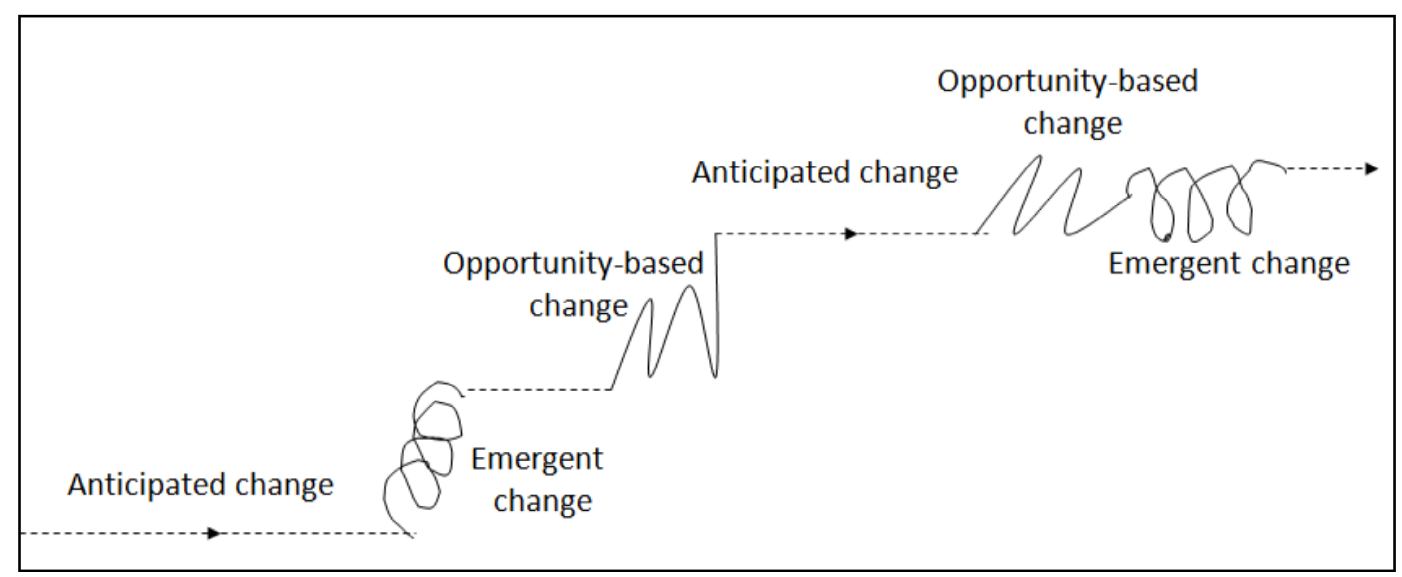

Sumber: Orlikowski \& Hofman (1997).

\section{Gambar 3. Model Perubahan Improvisasional}

Model perubahan improvisasional (Gambar 3) untuk mengelola perubahan teknologi didasarkan pada penelitian yang dilakukan Orlikowski dan Hofman (1997) pada pelaksanaan dan penggunaan teknologi informasi yang terbuka. Model ini terletak pada dua asumsi utama yang membedakannya dari model tradisional, yaitu: Pertama, perubahan yang terkait dengan implementasi teknologi merupakan suatu proses yang sedang berlangsung dengan titik akhir setelah perubahan dapat berharap untuk kembali pada keadaan yang cukup stabil. Kedua, semua perubahan teknologi dan organisasi yang dibuat selama berlangsungnya proses perubahan tidak bisa didasarkan hanya pada definisi saja, tetapi perlu diantisipasi sebelumnya. Orlikowski dan Hofman (1997) membedakan antara perubahan yang diantisipasi dan perubahan yang direncanakan sebelumnya, serta perubahan-perubahan yang timbul secara spontan (emergent change) dari inovasi lokal dan awalnya tidak diantisipasi atau dimaksudkan.

Model-model baru kepemimpinan terus berkembang, termasuk model kepemimpinan bagi organisasi bentuk baru, ketika kepemimpinan tidak lagi bergantung pada otoritas manajerial (Schneider, 2002). Menurut teori sistem secara umum, beberapa fenomena sistem yang dianggap: "hampir secara universal memiliki arti penting bagi semua disiplin ilmu" (Boulding, 1956). Fenomena ini termasuk populasi atau agregasi individu yang memiliki hubungan saling bergan- 
tung dan interaksi individu-individu dengan lingkungan mereka diatur oleh prinsip keseimbangan atau homeostasis. Perubahan organisasi adalah proses ketika organisasi bergerak dari posisi saat ini terhadap beberapa posisi di masa depan sebagai cara untuk meningkatkan keefektifannya secara keseluruhan (Jones, 2001). Manajemen perubahan adalah proses yang kompleks. Menurut Larkin dan Larkin (1996), manajemen perubahan adalah sesuatu yang banyak membuat organisasi melakukan kesalahan. Mereka menyoroti banyak CEO mengatakan bahwa mereka akan melakukan hal berbeda, jika mengelola berdasarkan inisiatif perubahan di masa depan. Hal yang demikian adalah cara mereka berkomunikasi dengan staf yang berbeda.

Seringkali, perubahan merupakan hasil dari sebuah krisis besar, baik internal maupun eksternal organisasi. Sadler (1998) menguraikan bahwa hal itu memerlukan visi besar dan keberanian untuk melihat perlunya perubahan organisasi dan untuk mencapainya sebelum krisis. Perubahan secara bertahap dilakukan dengan menggunakan informasi lingkungan yang tepat selama waktu lama dan sebagai informasi bersama yang diinternalisasi oleh karyawan, sebagai subsistem yang dapat dimodifikasi dan disesuaikan (Quinn, 1980). Banyak organisasi fokus pada satu elemen perubahan, seperti melihat struktur atau strategi, sedangkan program perubahan yang berhasil mengambil pandangan yang lebih lengkap dari semua elemen yang dapat mempengaruhi hasil akhir.

\section{MODEL MANAJEMEN PERUBAHAN}

Dalam menghadapi perubahan yang senantiasa akan terjadi secara kontinyu, manajer perlu memahami model atau pendekatan untuk mengantisipasinya. Beberapa model yang dapat digunakan adalah:

\section{Congruence Model}

Dalam melihat proses perubahan, model yang diajukan oleh Nadler dan Tushman (1979) disebut kongruensi model perilaku organisasi (Tabel 2), mengingat dalam hal membuat rekomendasi sekitar pendekatan pengembangan organisasi yang layak.

Tabel 2. Congruence Model untuk Manajemen Perubahan

\begin{tabular}{lll}
\hline \multicolumn{1}{c}{ Input } & \multicolumn{1}{c}{ Proses Transformasi } & \multicolumn{1}{c}{ Output } \\
\hline Lingkungan & Interaksi antarorganisasi & Pencapaian tujuan \\
\hline Sumber daya & Komponen & Penggunaan sumber daya \\
\hline Sejarah & Pekerjaan & Kinerja kelompok \\
\cline { 2 - 3 } & Individual & Perilaku individual \\
\cline { 2 - 3 } & Organisasi informal & \\
\hline
\end{tabular}

Sumber: Nadler \& Tushman (1979).

Titik utama model ini adalah semua elemen harus sejalan dalam rangka untuk untuk bekerja. Ada kebutuhan untuk memiliki sistem untuk mendukung proses perubahan, yang meliputi umpan balik reguler dari klien, pembinaan, pengembangan ketrampilan, menyiapkan contoh, dan monitoring sistem untuk memastikan perubahan terjadi. Dalam merekomendasikan pendekatan pengembangan organisasi, waktu akan dihabiskan pada tahap masukan dalam mempertimbangkan sejarah, nilai-nilai dan budaya organisasi, dan orangorang yang akan terpengaruh oleh perubahan. Pandangan mereka yang terli- 
bat harus ditetapkan dalam hal mana mereka sekarang yang membuat mereka melihat perlunya perubahan. Namun, salah satu kritik model ini adalah sistem yang sangat kongruen, sebenarnya memiliki resistensi terhadap perubahan karena berkembang melalui cara isolasi diri dari pengaruh luar (Burke, 1994). Di masa depan, ketika perubahan terjadi, staf akan melindungi diri dari perubahan selanjutnya di masa depan.

Tabel 3. TPC (Technical, Political, Cultural) Framework

\begin{tabular}{|c|c|c|c|}
\hline Sistem & Misi & Struktur & SDM \\
\hline Teknikal & $\begin{array}{ll}\text { - } & \text { Kebutuhan } \\
\text { penilaian } \\
\text { konsumen. } \\
\text { - } & \text { Mendefinisikan } \\
& \text { misi organisasi. } \\
\text { - } & \text { Mempertimbangka } \\
\text { n sumber daya } \\
\text { lebih. }\end{array}$ & $\begin{array}{ll}\text { - } & \text { Kebutuhan struktur } \\
\text { yang mendukung } \\
\text { strategi. } \\
\text { - } \quad \text { Kebutuhan peran } \\
\text { baru untuk } \\
\text { mengintegrasikan } \\
\text { - Struktur yang } \\
\text { mendukung } \\
\text { perubahan. } \\
\text { - Staf umpan balik } \\
\text { reguler. }\end{array}$ & $\begin{array}{ll}\text { - } & \text { Apakah staf yang } \\
\text { ada telah sesuai } \\
\text { dengan peran baru. } \\
\text { - } \quad \text { Bagaimana setiap } \\
\text { orang diukur dalam } \\
\text { peran barunya? } \\
\text { - } \\
\text { pencana } \\
\text { pembangunan } \\
\text { seperti apa yang } \\
\text { diperlukan untuk } \\
\text { menjalankan } \\
\text { organisasi? }\end{array}$ \\
\hline Politikal & $\begin{array}{ll}\text { - } & \text { Mendapatkan staf } \\
\text { inti untuk } \\
\text { mempengaruhi } \\
\text { misi dan strategi. } \\
\text { - } & \text { Mengelola perilaku } \\
\text { di sekitar } \\
\text { keputusan } \\
\text { strategik. }\end{array}$ & $\begin{array}{ll}\text { - } & \text { Bagaimana } \\
\text { kekuasaan } \\
\text { didistribusikan? } \\
\text { Staf perlu } \\
\text { diberdayakan } \\
\text { dalam peran baru } \\
\text { mereka. }\end{array}$ & $\begin{array}{ll}\text { - } & \text { Bagaimana staf } \\
\text { dipengaruhi di } \\
\text { dalam peran baru } \\
\text { mereka, baik itu staf } \\
\text { lama maupun baru? } \\
\text { Mendisain sistem } \\
\text { penghargaan untuk } \\
\text { mendukung } \\
\text { perubahan. } \\
\text { Mengelola penilaian } \\
\text { politik. }\end{array}$ \\
\hline Kultural & $\begin{array}{ll}\text { - } & \text { Adakah nilai-nilai } \\
\text { baru? } \\
\text { - } \quad \text { Bagaimana strategi } \\
\text { perubahan } \\
\text { mempengaruhi } \\
\text { bagaimana } \\
\text { organisasi } \\
\text { menjalankan } \\
\text { bisnis? } \\
\text { Membangun kultur } \\
\text { sesuai dengan misi } \\
\text { dan strategi. }\end{array}$ & $\begin{array}{l}\text { Membangun gaya } \\
\text { manajerial sesuai } \\
\text { dengan kultur baru. } \\
\text { - Membangun } \\
\text { subkultur yang } \\
\text { mendukung peran } \\
\text { baru. } \\
\text { Mengembangkan } \\
\text { identitas korporat } \\
\text { baru. }\end{array}$ & $\begin{array}{ll}\text { - } & \text { Memilih orang baru } \\
\text { untuk mendukung } \\
\text { perubahan. } \\
\text { Mengelola } \\
\text { penghargaan untuk } \\
\text { membentuk kultur } \\
\text { baru. } \\
\text { Mempertimbangkan } \\
\text { program pelatihan } \\
\text { dan pengembangan } \\
\text { yang diperlukan } \\
\text { untuk menjamin } \\
\text { adaptasi staf } \\
\text { terhadap perubahan. }\end{array}$ \\
\hline
\end{tabular}

Sumber: Tichy (1983).

\section{Model TPC Framework}

Tichy (1983) menyatakan bahwa rerangka TPC (Technical, Political, Cultural) adalah model lain yang berguna untuk mempertimbangkan dalam hal merekomendasikan intervensi pengembangan organisasi (OD). Model TPC ini menguraikan bagaimana strategi perubahan melibatkan pembuatan keputusan teknik, politik, dan budaya tentang keadaan organisasi yang baru. 
Ketika sebuah organisasi hanya berfokus pada satu atau dua unsur-unsur ini, perubahan akan mengalami disfungsional. Agar berhasil, tiga komponen tersebut perlu ditangani secara simultan. Manajemen strategi adalah tugas untuk menjaga tiga komponen tersebut dapat terurai dalam menghadapi masalah. Model ini telah menyajikan tiga tatanan dasar alat manajerial untuk menyelaraskan sistem teknik, politik, dan budaya dalam organisasi. Model ini mencakup: (1) Misi dan strategi organisasi, (2) Struktur organisasi, dan (3) Prosedur manajemen sumber daya manusia. Ketika melihat pada elemenelemen teknik, politik, dan budaya di dalam organisasi, suatu kebijakan dibuat di setiap area cakupan model tersebut sebesar perubahan yang diperlukan.

\section{Model 7S McKinsey}

Sadler (1998) menyebutkan bahwa keberhasilan organisasi tergantung pada

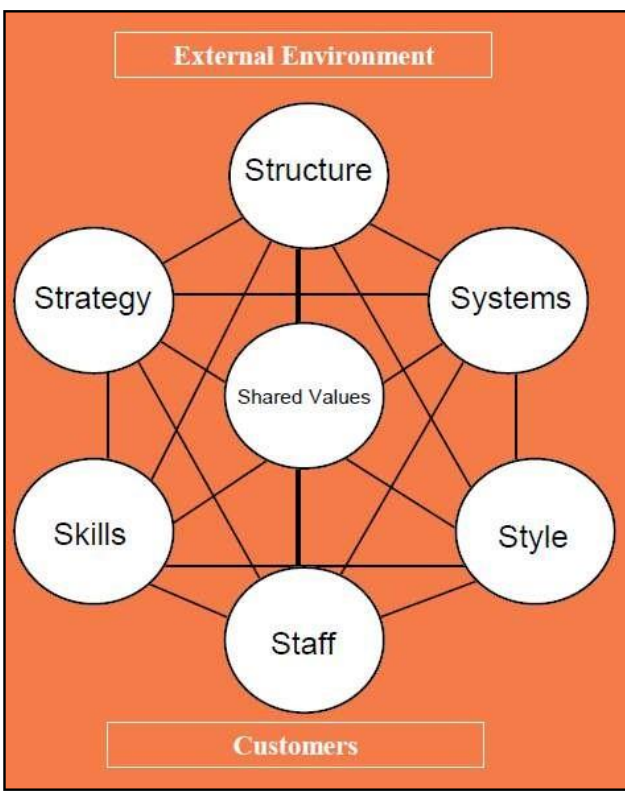

Sumber: Sadler (1998). penyusunan dan pelaksanaan tujuh elemen "S" McKinsey (Gambar 4). Seperti halnya model Tichy (1983) dan Nadler dan Tushman (1979), model 7S McKinsey memfokuskan pada upaya penyeimbangan penataan staf, struktur, dan tujuan organisasi. Dalam banyak kasus, strategi menempati tempat paling krusial, tetapi area kunci kegagalan berada di sekitar proses penataan staf. Kelompok khusus seharusnya dipertimbangkan bersama dengan cara wawancara staf tatap muka untuk menentukan bagaimana mereka merasakan peran mereka sekarang, sebagaimana identifikasi apa yang diperlukan untuk berubah di masa depan.

\section{Gambar 4. Model 7S McKinsey}

\section{PENGEMBANGAN ORGANISASI}

Pengembangan Organisasi/PO (Organizational Development/OD) pada prinsipnya merupakan suatu proses ketika pengetahuan, konsep, dan praktik yang berkaitan dengan (perilaku) organisasi digunakan secara efektif untuk membantu organisasi dalam mencapai tujuannya. Proses ini juga termasuk bagaimana meningkatkan kualitas kinerja organisasi dan sekaligus meningkatkan produktifitas (anggota) organisasi. Pengembangan organisasi pada dasarnya berbeda dengan berbagai upaya perubahan organisasi yang dilakukan secara terencana, seperti upaya perubahan dengan melakukan pembelian peralatan baru, atau merancang ulang sebuah disain, atau pun menyusun ulang suatu kurikulum sekolah, atau suatu departemen pada suatu fakultas. Hal ini karena fokus kajian OD itu terletak pada peningkatan kemampuan organisasi untuk dapat mengetahui dan memecahkan berbagai masalah yang dihadapi organisasi itu sendiri. Dengan demikian, pengembangan organisasi pada kenyataannya berorientasi pada pening- 
katan atau kemajuan (kinerja) sistem; yaitu organisasi sebagai suatu sistem dengan bagian-bagian yang terdapat di dalamnya dapat mempengaruhi atau memberi dampak (positif) dalam interaksinya dengan lingkungan yang lebih luas lagi, yaitu lingkungan di luar organisasi.

Pengembangan organisasi memang merujuk kepada konsep pengembangan yang prosesnya terjadi secara perlahan dan memerlukan waktu yang (sangat) panjang. Jadi pengembangan organisasi bersifat evolutif. Hal ini terjadi karena kegiatan pengembangan organisasi itu sangat bervariasi dan menyangkut aspekaspek organisasi. Sebagai contoh, pembentukan suatu tim pengembang atau tim evaluasi yang dipimpin oleh kalangan manajemen suatu perusahaan dalam mengkaji kinerja organisasi perusahaan. Contoh lain menyangkut perubahan struktural di suatu kecamatan. Atau, dapat juga tentang peningkatan kualifikasi anggota suatu organisasi melalui berbagai kursus, pelatihan, dan magang. Semua itu merupakan aspek-aspek pengembangan organisasi. Penelitian mengenai pengembangan organisasi sebenarnya juga merupakan upaya untuk mengatasi berbagai isu yang timbul, atau berbagai masalah yang muncul, termasuk masalahmasalah yang muncul sebagai dampak berbagai perubahan yang terjadi. Studi ini juga menyangkut cara-cara yang digunakan di dalam melakukan perubahan organisasi, termasuk faktor-faktor yang mempengaruhi keberhasilan dalam melakukan perubahan organisasi.

Menurut Cummings (1989), pengembangan organisasi adalah suatu aplikasi konsep atau teori dengan menggunakan suatu sistem, ketika konsep ilmu pengetahuan digunakan untuk mengembangkan organisasi secara terencana dan dengan menggunakan semua strategi yang dimiliki organisasi untuk meningkatkan efektivitas kinerja organisasi. Selanjutnya, Cummings (1989) juga menyatakan bahwa konsep (ilmu pengetahuan) di dalam pengembangan organisasi itu pada dasarnya merupakan faktor-faktor yang membedakan pengembangan organisasi dengan pendekatan lain dalam kaitannya dengan peningkatan kinerja organisasi. Faktorfaktor tersebut antara lain menyatakan bahwa:

1. Pengembangan organisasi dapat diaplikasikan pada semua sistem, seperti pada perusahaan, atau pada satu bidang usaha saja dari perusahaan yang memiliki banyak bidang usaha. Pengembangan organisasi juga dapat diterapkan pada satu bagian dari sebuah kelompok usaha. Hal ini berbeda dengan berbagai pendekatan yang umumnya memfokuskan pada satu atau sebagian kecil aspek saja dari sebuah sistem, seperti sistem informasi manajemen/MIS (Management Information System) atau bagian konsultasi pegawai misalnya.

2. Pengembangan organisasi juga didasarkan pada praktik-praktik dan ilmu pengetahuan (mengenai perilaku) seperti kepemimpinan, dinamika kelompok, disain pekerjaan, serta berkaitan juga dengan berbagai pendekatan yang bersifat makro, seperti strategi organisasi, struktur organisasi, dan hubungan lingkungan dengan organisasi. Jadi, pada kenyataannya, pengembangan organisasi berbeda dengan pendekatan yang menekankan pada penerapan riset operasi (seperti pada bidang mekanika) yang memfokuskan pada hal-hal yang sifatnya teknis/rasional dan mengabaikan aspek-aspek personal dan sosial (dari anggota organisasi).

3. Meskipun pengembangan organisasi terfokus pada perubahan yang direncanakan, tetapi sebenarnya pengembangan organisasi bukanlah sesuatu yang sifatnya kaku (rigid), formal, yang biasanya dikaitkan dengan perencanaan 
bisnis. Strategi pengembangan organisasi cenderung lebih adaptif dalam hal perencanaan dan aplikasinya. Oleh karena itu, pengembangan organisasi bukanlah sekedar sebuah rancang bangun (blueprint) belaka yang menyangkut bagaimana sesuatu itu dapat dikerjakan. Jadi, pengembangan organisasi pada dasarnya melibatkan perencanaan mengenai bagaimana mendiagnosis masalah-masalah yang dihadapi organisasi dan bagaimana memberikan solusinya. Hanya saja, di dalam pengembangan organisasi, perencanaan semacam itu sifatnya fleksibel dan mudah direvisi, diubah sesuai kebutuhan, berkaitan dengan informasi baru yang berisi mengenai bagaimana program-program perubahan dilaksanakan. Namun, yang menjadi pusat perhatian adalah motivasi kerja para pegawai, berbagai program pengayaan kerja (job enrichment) boleh saja direncanakan untuk diterapkan atau dilaksanakan di awal-awal kegiatan. Hal ini dimaksudkan agar organisasi dapat mengakses, mengidentifikasi, dan mengetahui motivasi-motivasi potensial para pekerja atas pekerjaan-pekerjaan yang sudah ada. Selain itu, hal tersebut juga dapat digunakan untuk merancang ulang pekerjaan-pekerjaan tersebut bila diperlu-kan. Rancangan atau rancang ulang itu dapat saja dimodifikasi bila dari hasil penilaian atau evaluasi ditemukan bahwa yang menjadi masalah bukanlah perencanaannya melainkan reward system, atau kehadiran pegawai, sehingga hal itulah yang dianggap sebagai penyebab motivasi para pegawai merosot.

4. Pengembangan organisasi juga diawali dari implementasi program-program perubahan untuk jangka panjang yang fokusnya menyangkut stabilisasi dan pelembagaan perubahan di dalam organisasi. Contohnya, implementasi program-program peningkatan kualifikasi pegawai dapat difokuskan pada bagaimana cara-cara yang telah dilakukan para supervisor (pengawas/mandor) untuk dapat memotivasi para pegawai atau pekerja agar mereka dapat melakukan kontrol secara lebih ketat atas cara-cara kerja para pegawai. Setelah aspek pengawasan berhasil, maka fokus berikutnya mengenai faktor-faktor yang dapat menjamin bahwa organisasi tetap dapat memberikan kebebasan kepada para pengawas atau mandor untuk melakukan kontrol terhadap para pekerja. Jaminan ini termasuk memberikan hadiah (reward) bagi para mandor/pengawas bila mereka melakukan pekerjaannya secara partisipatif.

5. Pengembangan organisasi sangat memperhatikan strategi, struktur, dan proses perubahan. Program perubahan bertujuan untuk memodifikasi strategi organisasi. Contohnya, program perubahan yang difokuskan pada bagaimana organisasi berhubungan dengan lingkungan yang lebih luas; bagaimana hubungan itu dapat dipelihara dan ditingkatkan. Hal ini juga termasuk perubahan, baik pada kelompok orang di dalam mengerjakan tugas-tugas (aspek struktur); dalam metode-metode komunikasi dan cara-cara memecahkan masalah (aspek proses), yang kesemuanya diterapkan untuk mendukung perubahan strategi secara keseluruhan. Sejalan dengan hal tersebut, programprogram pengembangan organisasi juga ditujukan untuk membantu tim manajemen agar kinerjanya menjadi lebih efektif dalam memfokuskan pada berbagai interaksi dan proses-proses pemecahan masalah di dalam kelompok. Harapannya adalah upaya tersebut menunjukkan kemampuan tim manajemen untuk memecahkan masalah-masalah atau kendala-kendala yang muncul di dalam organisasi dapat ditingkatkan secara optimal. 
6. Pengembangan organisasi juga berorientasi untuk meningkatkan efektifitas organisasi. Atas hal ini ada dua asumsi dasar yang dikemukakan: Pertama, organisasi yang efektif akan mampu memecahkan masalah-masalah yang dihadapinya, sehingga pengembangan organisasi sebenarnya menolong (para) anggota organisasi untuk mendapatkan kemampuan dan pengetahuan yang dibutuhkan dalam memecahkan masalah-masalah dimaksud. Hal ini agak berbeda dengan bentuk-bentuk lain dari perubahan yang direncanakan ketika seorang konsultan (yang disewa dari luar), misalnya, selain akan secara langsung memecahkan masalah yang dihadapi organisasi, ia juga akan merekomendasi solusi-solusi terhadap masalah-masalah yang dihadapi organisasi ketika kemampuan (para) anggota untuk memecahkan masalahmasalah yang muncul menjadi tidak terasah dengan baik. Kedua, organisasi yang efektif memiliki kualitas kerja dan produktifitas yang sangat tinggi. Hal ini akan menarik minat sekaligus akan memotivasi para pegawai untuk bekerja secara efektif. Lebih jauh lagi, organisasi akan sangat responsif, lebih tanggap atas berbagai kebutuhan kelompok-kelompok eksternal (para pemegang saham, para pelanggan, para pemasok, dan pemerintah) yang menyediakan berbagai kemudahan atau fasilitas serta sumber daya bagi organisasi.

Pada dasarnya, pengembangan organisasi dapat membantu suatu organisasi untuk menciptakan respon yang sangat efektif atas berbagai perubahan. Dalam banyak kasus, pengembangan organisasi akan mempengaruhi arah strategi organisasi. Menurut beberapa pengamat dan berdasar pada beberapa studi yang telah dilakukan, banyak sekali organisasi yang terjebak di dalam ketidakpastian dan menjadi kacau kinerjanya, sehingga tidak ada lagi yang dapat dilakukan oleh manajemen untuk 'menyelamatkan' organisasi tersebut. Berkaitan dengan hal itu, Peters (1987) menunjukkan sejumlah faktor penekan yang dihadapi oleh organisasi-organisasi modern. Faktor-faktor tersebut yang dianggap telah mempengaruhi lingkungan organisasi, sehingga mengacaukan kinerjanya. Pressure factors tersebut antara lain (Peters, 1987):

1. Berkembangnya revolusi teknologi dengan berbagai inovasinya yang menyangkut disain atau rancangan, pembuatan atau proses produksi, serta distribusi produk-produk, baik berupa barang maupun jasa. Contohnya, merancang dan memproduksi barang dengan menggunakan (bantuan) komputer, adanya jaringan elektronik yang mencakup prosedur kerja seperti penggunaan LAN (Local Area Network), keterlibatan para pelanggan, dan juga para pemasok.

2. Adanya persaingan sangat ketat dengan negara-negara yang industrinya sudah berkembang pesat atau dengan negara-negara yang industrinya baru berkembang, seperti antara Amerika atau Jerman dengan Jepang, Korea, dan China, dan sebagainya.

3. Banyaknya organisasi yang melakukan merger atau penyatuan usaha, melakukan akuisisi, divestasi, leverage buyouts, dan joint venture berkaitan dengan jatuh bangunnya sebuah bisnis.

4. Adanya permintaan konsumen atas barang dan jasa yang semakin tinggi, serta berkaitan dengan kualitas produk dan convenience. Convenience terutama terkait dengan masalah kemudahan dalam mendapatkan suatu produk. 
5. Pengaruh globalisasi yang terasa dampaknya pada bidang bisnis, nilai tukar uang, kebijakan perdagangan, dan situasi politik yang ke semuanya semakin menyatu, berubah dengan cepat, serta tidak dapat diandalkan (volatile), misalnya tidak dapat diandalkan untuk dijadikan dasar prediksi bisnis.

6. Tenaga kerja yang menuntut untuk semakin terlibat di dalam berbagai kegiatan organisasi dan menuntut hak untuk ikut memutuskan apa yang paling cocok bagi mereka untuk dikerjakan. Hal ini terutama terkait dengan reward system, serta berkaitan juga dengan peningkatan yang sangat cepat menyangkut jumlah keluarga yang memiliki dua sumber penghasilan.

7. Tuntutan masyarakat atas penurunan pajak, berkurangnya pengendalian pemerintah atas berbagai hal yang menyangkut pajak, ketika masyarakat semakin berharap agar pemerintah tanggap atas semua tuntutan tersebut.

Berbagai faktor tersebut seringkali saling berkaitan dan implikatif, ketika semua hal dapat berubah secara cepat, sehingga membuat keadaan menjadi tidak menentu atau tidak pasti. Hal itu pulalah yang merusak dan mengacaukan kinerja organisasi perusahaan, baik manufaktur maupun industri jasa yang menyangkut kinerja organisasi-organisasi perusahaan manufaktur dan industri jasa, baik pemerintah maupun swasta. Pengembangan organisasi memang memegang peranan penting dalam membantu organisasi untuk mengubah dirinya sendiri, melalui strategi yang sangat terencana dan dengan prediksi masalah yang mungkin dapat diatasi melalui solusi-solusi yang diberikan. Pengembangan organisasi juga dapat menolong organisasi untuk mengetahui berbagai kelemahan yang dimiliki dengan tujuan untuk membangun kembali strategi, struktur, dan proses yang selama ini telah dijalankannya.

Pengembangan organisasi juga membantu anggota organisasi untuk lebih dapat menyelami perubahan dan mengelola asumsi-asumsi serta nilai-nilai yang mendasari kinerja organisasi. Dalam kaitan dengan pengembangan kemampuan pegawai, pengembangan organisasi dapat membantu untuk meningkatkan karir pegawai, dan meningkatkan kualifikasi pegawai, serta dapat mempererat jalinan hubungan dan kerjasama antara pegawai dan pihak manajemen. Pengembangan organisasi sangat berperan di dalam pengawasan (supervisi), meningkatkan dan mengembangkan kinerja staf dan kinerja organisasi, serta berperan dalam mengenalkan metode-metode baru dalam memberikan konseling. Pengembangan organisasi juga membantu staf untuk bekerja secara efektif dan efisien, membantu membina hubungan kerja yang efektif, sehingga dapat menunjukkan kepada semua pegawai bagaimana seharusnya bekerja dengan orang lain secara efektif dalam memecahkan masalah-masalah yang kompleks dan memberikan solusi yang tepat.

\section{HIGH-PERFORMANCE ORGANIZATION (HPO)}

De Waal (2004) menerangkan bahwa pengertian High-Performance Organization (HPO) adalah suatu organisasi yang mencapai hasil finansial lebih baik daripada organisasi lain yang sejenis dalam jangka panjang, dengan kemampuan adaptasi terhadap perubahan dan melakukan reaksi terhadap perubahan dengan cepat, dengan kemampuan mengelola dalam jangka panjang, dengan menetapkan suatu struktur manajemen yang terintegrasi dan terkoneksi, dengan melakukan perbaikan secara berkelanjutan terhadap kemampuan intinya, dan dengan perlakuan karyawan yang sungguh-sungguh sebagai aset utama. Dengan 
adanya tekanan peningkatan permintaan lingkungan eksternal dan stakeholders, organisasi akan selalu mencari elemen-elemen untuk membuatnya meraih kinerja terbaik.

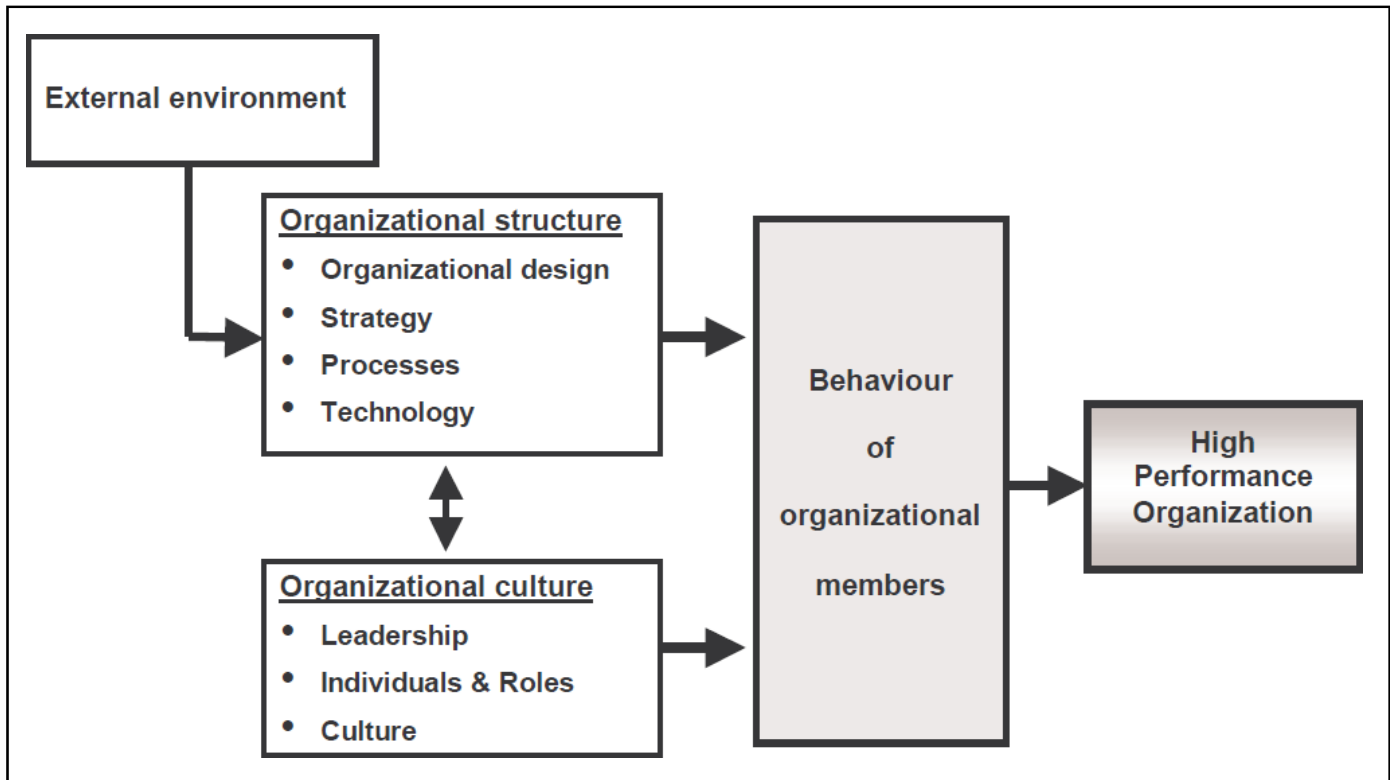

Sumber: De Waal (2004).

\section{Gambar 5. High Performance Organization (HPO)}

Karakteristik HPO akan terkait dengan disain organisasional, struktur, proses, teknologi, kepemimpinan, orang, dan budaya. Lingkungan eksternal akan mempengaruhi kemampuan organisasi untuk meraih kinerja terbaik. Karakteristik ini dapat memandu manajer untuk bertindak sebagaimana mereka perlukan untuk mengarahkan pada hasil superior. Dengan maksud untuk mengelompokkan HPO, sebuah rerangka menurut Kotter dan Heskett (1992) dikombinasikan dengan Morton (2003). Rerangka Kotter dan Heskett mengidentifikasikan empat faktor yang mempengaruhi perilaku orang dalam organisasi, yaitu: (1) budaya organisasi; (2) struktur organisasi yang mencakup struktur formal, sistem, proses, dan kebijakan; (3) kepemimpinan organisasi; dan (4) lingkungan eksternal yang meliputi pesaing, publik, dan organisasi pemerintah. Morton (2003) memperluas faktor lingkungan eksternal dengan menambahkan konsumen, pemasok, dan mitra kerja, serta memperluas rerangka tersebut dengan meletakkan individual dan peran di dalamnya dan secara khusus menambahkan strategi, disain organisasi, dan teknologi ke dalam faktor struktur organisasi (Gambar 5).

Bhalla et al. (2011) menyebutkan 14 karakteristik HPO yang terkelompok dalam lima kategori, yaitu: (1) kepemimpinan, (2) disain, (3) orang, (4) manajemen perubahan, dan (5) budaya dan keterikatan. Karakteristik HPO menurut BCG tersebut diuraikan dalam Gambar 6 berikut ini. Suatu pola kepemimpinan yang terhubung antara pemimpin dan pengikut akan membuat keefektifan di dalam organisasi. Disain struktur organisasi harus merefleksikan fokus strategi organisasi dan memiliki peran yang jelas dan akuntabel. Komponen orang atau sumber daya manusia merupakan kunci keefektifan organisasi melalui penterjemahan strategi bisnis ke dalam strategi yang kuat untuk mencari dan mempertahankan individu yang paling memiliki kemampuan. Organisasi juga perlu memi- 
liki kemampuan untuk mengarahkan dan manajemen perubahan dalam skala yang luas dan mengantisipasi dan adaptasi terhadap ketidakpastian lingkungan yang semakin meningkat. Selain itu, budaya terbentuk untuk mencapai tujuan strategis dan karyawan termotivasi berusaha meraih lebih dari tujuan organisasi.

\begin{tabular}{||c|c|}
\hline LEADERSHIP & $\begin{array}{l}\text { - High-performance teams of individual leaders drive urgency } \\
\text { and direction } \\
\text { - The pipeline is stocked with future leaders whose skills are } \\
\text { matched to future needs } \\
\text { - Middle managers embrace and translate strategy }\end{array}$ \\
\hline DESIGN & $\begin{array}{l}\text { - Structure and resource allocation reflect strategic tradeoffs } \\
\text { - Few layers separate the CEO and the frontline, and spans of } \\
\text { control are wide } \\
\text { - Accountabilities, decision rights, and collaboration are } \\
\text { constructed with thoughtful consideration } \\
\text { - Individual capabilities are matched to role requirements }\end{array}$ \\
\hline PEOPLE & $\begin{array}{l}\text { - The employer brand is a core asset } \\
\text { - Critical roles and key talents are clearly identified and treated } \\
\text { with care } \\
\text { - HR is a strategic partner and an enabler of the business }\end{array}$ \\
\hline CHANGE MANAGEMENT & $\begin{array}{l}\text { - Change is a disciplined cascade } \\
\text { - The organization is evolutionary }\end{array}$ \\
\hline ENGAGEMENT & $\begin{array}{l}\text { - Culture accelerates strategic objectives } \\
\text { - Engagement is measured and cultivated to generate } \\
\text { discretionary effort from employees }\end{array}$ \\
\hline
\end{tabular}

Sumber: BCG (2011).

\section{Gambar 6. Karakteristik High-Performance Organization}

Overholt et al. (2007) menyebutkan bahwa terdapat cukup sejarah dan teori di balik gagasan organisasi berkinerja tinggi (HPO). Dari teori dan praktik bisnis yang sukses, para ahli telah banyak mengemukakan berbagai prinsip kinerja tinggi. Dari Weber, misalnya, wawasan tentang pentingnya struktur dan proses organisasi. Drucker dan Van de Ven menunjukkan kebutuhan untuk menyelaraskan perilaku dan strategi. Deming menyoroti kebajikan untuk mengukur kinerja manusia, proses, dan hasilnya. Dari banyak literatur tersebut, sebuah model kinerja tinggi yang berpusat pada lima karakteristik utama organisasi dapat dirumuskan (Gambar 7).

Pertama, karakteristik yang berkaitan dengan pendekatan strategis (strategic approcah). Organisasi seharusnya konsisten dalam menerapkan pendekatan strategis untuk membantu menentukan keberhasilannya. Konsistensi ini dapat diukur dengan melihat seberapa baik organisasi beroperasi dengan kinerja tinggi untuk membangun visi yang jelas dan didukung oleh fleksibilitas dan dapat dicapai melalui rencana strategis. Selain itu, penetapan standar perilaku untuk semua orang di dalam organisasi perlu dilakukan. Pemimpin, manajer, dan karyawan harus berperilaku konsisten dengan rencana strategis dan filosofi perusahaan. 
Kedua, karakteristik yang terkait dengan pendekatan pelanggan (customer approach) yaitu upaya organisasi memperlakukan dan melayani pelanggan. Organisasi berkinerja tinggi cenderung memiliki pendekatan yang jelas untuk memperoleh pelanggan baru, memperlakukan pelanggan saat ini dengan baik, dan mempertahankan pelanggan yang sudah ada. Organisasi juga perlu membangun infrastruktur dan proses yang diperlukan untuk mendukung penerapan pendekatan pelanggan.

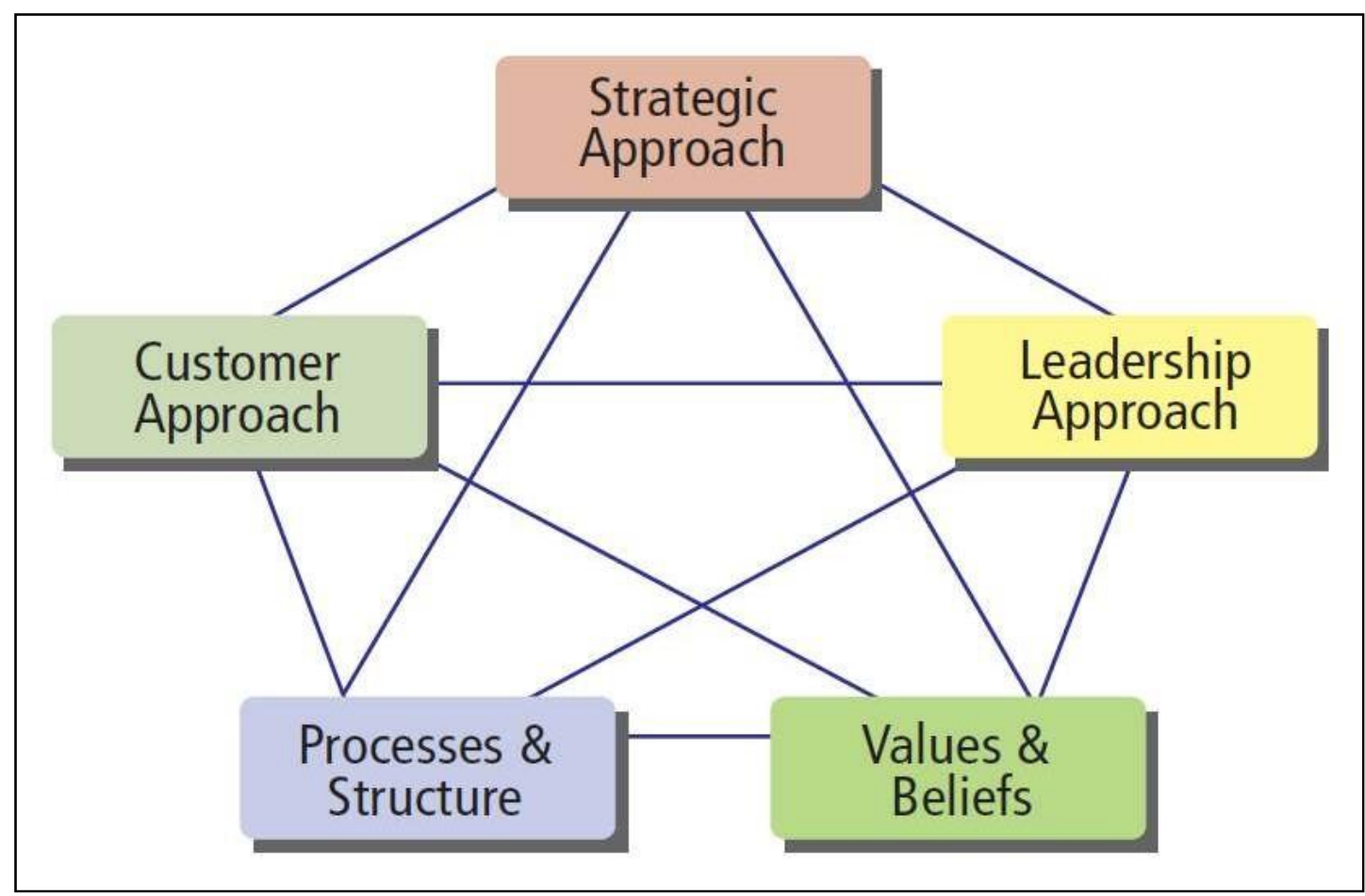

Sumber: Overholt et al. (2007).

\section{Gambar 7. Komponen Interaktif High-Performance Organization}

Ketiga adalah pendekatan kepemimpinan (leadership approach). Pendekatan ini menjelaskan strategi organisasi dalam mengelola orang untuk mencapai satu kondisi tertentu dari perilaku orang-orang di dalam organisasi sesuai filosofi organisasi. Organisasi berkinerja tinggi memiliki kejelasan tentang perilaku karyawan seperti apa yang untuk menjalankan organisasi dan strateginya. Eksekutif dan manajer menetapkan tujuan yang jelas, memahami kemampuan karyawan, dan membimbing kinerja mereka.

Keempat adalah proses dan struktur (processes and structure). Pendekatan ini menentukan bagaimana organisasi mengatur proses kerja, kebijakan, dan prosedur untuk mendukung dan melaksanakan strategi. Organisasi berkinerja tinggi memiliki proses yang memperkuat strategi, menyiapkan arus kerja dan tugastugas yang paling efektif memungkinkan karyawan untuk memenuhi kebutuhan internal dan pelanggan eksternal di dalam batasan-batasan strategi organisasi. Organisasi seperti ini akan cenderung menggunakan berbagai matriks untuk mengukur pekerjaan masing-masing departemen dan organisasi secara keseluruhan. 
Kelima adalah nilai-nilai dan keyakinan (values and beliefs). Komponen ini penting untuk membantu organisasi melaksanakan strategi dan mencapai misinya. Organisasi berkinerja tinggi biasanya memiliki seperangkat nilai-nilai yang merupakan driver bagi perilaku karyawan dan dipahami dengan baik oleh sebagian besar karyawan. Nilai-nilai dan keyakinan yang tertanam dalam organisasi dan konsisten dengan pendekatan kepemimpinan.

Tinjauan kelima faktor atau karakteristik HPO ini yang utama berfungsi sebagai driver untuk mempengaruhi kinerja organisasi. Masing-masing berinteraksi dan saling mempengaruhi satu dengan lainnya untuk menciptakan sistem organisasi secara keseluruhan. Perubahan satu faktor akan menciptakan perubahan pada faktor yang lain. Selanjutnya, sistem cenderung akan berubah secara kontinyu seiring dengan perubahan faktor dan kondisi lingkungan eksternal. Interaksi antara kelima karakteristik tersebut diilustrasikan dalam Gambar 7 di atas. Young (2005) berpendapat bahwa untuk mencapai kinerja tinggi, organisasi perlu mempraktikkan lima kualitas organisasi berkinerja tinggi baik bagi organisasi perusahaan maupun sektor nirlaba. Lima kualitas kinerja tinggi tersebut adalah:

1. Commitment to excellence: Organisasi berkinerja tinggi mengintegrasikan standar bagi keunggulan mereka dalam tata kelola, manajemen, dan program operasi.

2. Clearly stated purpose and desired results: Organisasi berkinerja tinggi telah menyatakan dan mendefinisikan maksud dan tujuan dengan jelas, sehingga menjadi alasan keberadaan organisasi dan mengilhami orang lain untuk bergabung. Mereka mampu memahami hubungan antara peran individu dan visi, misi, nilai-nilai dan hasil yang diinginkan oleh organisasi.

3. Effective change management process: Organisasi tidak akan mampu untuk bertahan tanpa perubahan, ketika begitu banyak hal di sekitar mereka yang berubah. Organisasi-organisasi tidak hanya harus siap untuk beradaptasi, tetapi mereka harus memiliki pemimpin yang dapat mengelola proses perubahan secara efektif.

4. Open, multi-directional communication: Organisasi berkinerja tinggi membangun sistem dan metode yang efektif untuk berkomunikasi dan setiap orang diharapkan mampu menggunakannya. Orang-orang di dalam organisasi berkinerja tinggi menggunakan tim lintas fungsional. Organisasi perlu terbuka dan menggunakan komunikasi multiarah yang lebih baik untuk mencegah atau mengatasi masalah-masalah secara efektif.

5. Culture of continuous learning: sebuah organisasi dengan menerapkan budaya untuk belajar secara terus menerus akan menghasilkan hasil yang luar biasa. Dalam organisasi berkinerja tinggi, proses pembelajaran didorong terjadi di semua tingkatan organisasi dan melalui berbagai metode. Orang-orang di dalam organisasi berkinerja tinggi menilai kebutuhan belajar mereka dan menciptakan rencana pengembangan profesional.

\section{KESIMPULAN}

Lingkungan bisnis (business environment) memiliki pengaruh yang kuat terhadap organisasi perusahaan, terlebih kondisi saat dunia bisnis sudah tidak terbatas oleh suatu teritorial negara (borderless world). Persaingan yang semakin ketat di masa mendatang memerlukan kreasi strategi baru berupa pola strategi 
yang spesifik dan memadai. Pola tersebut seharusnya dapat menampung perubahan-perubahan yang terjadi di lingkungan bisnis di masa mendatang.

Organisasi yang berhasil menyelaraskan atau yang menunjukan tingkat adaptif dan fleksibilitas tinggi dengan lingkungan akan memperlihatkan kinerjanya lebih baik daripada organisasi yang kurang berhasil menyelaraskan strategi atau menunjukkan tingkat adaptif dan fleksibilitas yang rendah. Suatu tindakan yang inovatif dan rasional dimaksudkan bagi kemampuan manajemen puncak dalam memposisiskan organisasi yang dikelolanya berkaitan dengan pengaruh lingkungan internal organisasi (internal environment) maupun pengaruh lingkungan eksternal organisasi (external environment). Kemampuan dan pemahaman tersebut akan mendorong lahirnya strategi yang mampu menjadi solusi terbaik dalam memanfaatkan peluang (opportunities) sekecil apa pun untuk menutupi kelemahan (weaknessess). Di samping itu, organisasi perlu memanfaatkan kekuatan (strengths) yang ada untuk menghadapi atau menghindari ancaman (threats) agar organisasi tetap dapat mempertahankan kesinambungan (survival), pertumbuhan (growth), dan meningkatkan kinerjanya (performance).

Manajer maupun organisasi secara keseluruhan perlu menyadari dan memahami berbagai kekuatan lingkungan bisnis yang mempengaruhinya. Pengaruh tersebut dapat memberikan konsekuensi positif maupun negatif. Kemampuan manajer mengelola organisasi dan lingkungan bisnisnya menjadi sebuah tuntutan perkembangan perilaku organisasional. Mengingat tingkat perubahan yang semakin cepat dan kontinyu, organisasi akan menghadapi kondisi turbulensi lingkungan yang semakin tinggi. Organisasi akan membutuhkan suatu kemampuan lebih untuk dapat bereaksi cepat dan mengantisipasi berbagai turbulensi yang dihadapinya secara tepat. High-performance organization (HPO) merupakan solusi untuk menghadapi perubahan yang semakin sulit diprediksikan. HPO akan memberikan kemampuan bagi organisasi melalui: (1) budaya organisasi, (2) struktur organisasi, (3) kepemimpinan organisasi, dan (4) lingkungan eksternal. Untuk mencapai organisasi berkinerja tinggi, organisasi perlu mempraktikkan lima komponen pendekatan yang terintegrasi meliputi: (1) pendekatan strategik, (2) pendekatan pelanggan, (3) pendekatan kepemimpinan, (4) pendekatan proses dan struktur, dan (5) pendekatan nilai dan keyakinan.

\section{DAFTAR REFERENSI}

Bhalla, V., Caye, J., Dyer, A., Dymond, L., Morieux, Y., \& Orlander, P. (2011). High-Performance Organization: The Secrets of Their Success. The Boston Consulting Group (BCG), (September).

Boulding, K.E. (1956). General Systems Theory: The Skeleton of Science. Management Science, 2(3).

Burke, W.W. (1994). Organisation Development: A Process of Learning and Changing. Massachusetts: Addison-Wesley, Inc.

Chen, J., Suen, M., Lin, M., \& Shieh, F. (2013). Organizational Change and Development. National Academy of Civil Service, 100(2), (March).

Cummings, G.T. \& Huse, E.F. (1989) Organization Development and Change, ( $4^{\text {th }}$ edition $)$. USA: West Publishing Company. 
De Waal, A.A. (2004). The Characteristics of a High Performance Organization. Performance Management. Maastricht School of Management.

Haveman, H.A., Russo, M.V., \& Meyer, A.D. (2001). Organizational Environments in Flux: the Impact for Regulatory Punctuations on Organizational Domains: CEO Succession and Performance. Organization Science, 12.

Jones, G.R. (2001). Organizational Theory. New Jersey: Prentice-Hall International, Inc.

Kotter, J.P. (1996). Leading Change. Boston: Harvard BS Press.

Kotter, J. P. \& Heskett, J.L. (1992). Corporate Culture and Performance.

Kusmayadi, D. (2008). Pengaruh Lingkungan Bisnis terhadap Kinerja Perusahan: Sebuah Tinjauan Teoritis dan Empiris. Jurnal Akuntansi FE Unsil, 3(2).

Laing, R.D. (2000). cited in Walsh, E. (2000), Making the Case for Change. Logistics Management and Distribution Report. Radnor, (October).

Larkin, T.J. \& Larkin, S. (1996). Reaching and Changing Frontline Employees. Harvard Business Review, (May-June).

Luthans, F. (2011). Organizational Behavior: An Evidence-Based Approach, (12th Edition). New York: McGraw-Hill Book.

Mardiyono, A. (2005). Pengaruh Faktor Lingkungan Bisnis Eksternal dan Faktor Manajerial terhadap Perencanaan Strategik untuk Meningkatkan Kinerja Perusahaan. Jurnal Ilmiah Serat Acitya.

Morton, C. (2003). Beyond World Class. Basingstoke: MacMillan Business.

Orlikowski, W.J. \& Hofman, J.D. (1997). An Improvisational Model for Change Management: The Case of Groupware Technologies. Sloan Management Review, (Winter).

Overholt, M.H., Dennis, D.J., Lee, J.M., Morrison, C.L., \& Vickers, M. (2007). How to Build A High-Performance Organization: A Global Study of Current Trends and Future Possibilities 2007-2017. American Management Association (AMA).

Peranginangin, P. (2013). Pengaruh Ketidakpastian Lingkungan, Strategi Bisnis dan Kebijakan Teknologi terhadap Kinerja Perusahaan: Studi Empirik Perusa-haan Tekstil dan Garmen Indonesia, 2005-2008. Journal of Business and Entrepreneurship, 1(1), (January).

Peters, T. (1987). Thriving on Chaos: A Handbook for a Management Revolution. New York: Knopf Publishing Company.

Prakarsa, W. (1994). Sistem Pengukuran Kinerja-Pendekatan Kontemporer, Strategi Pembiayaan dan Regrouping BUMN. Jakarta: FE-UI.

Quinn, J.B. (1980). Managing Strategic Change. Sloan Management Review. 21(4), (Summer).

Robbins, S.P. \& Judge, T.A. (2013). Organizational Behavior, (15th Edition). New Jersey: Pearson Education, Inc. 
Sadler, P. (1998). Management Consultancy: A Handbook for Best Practice. London: Kogan Page Limited.

Schneider, M. (2002). A Stakeholder Model of Organizational Leadership. Organization Science, 13(2).

Schneider, M. \& Somers, M. (2006). Organizations as Complex Adaptive Systems: Implications of Complexity Theory for Leadership Research. The Leadership Quarterly, 17.

Senge, P.M. (2010). The Fifth Discipline: The Art and Practice of the Learning Organization. Random House Publishing.

Tichy, N.M. (1983). Managing Strategic Change: Technical, Political, and Cultural Dynamics. New York: Wiley \& Sons Co.

Young, N.M. (2005). 5 Qualities of High Performance Organization. Optimal Solutions Consulting. www.opti-solutions.com. 